\title{
Antecedent Factors of Attitude toward Corruption: an Empirical Study of Indonesian Students Context
}

\author{
Sabrina O. Sihombing \\ Management Department \\ Business School - Universitas Pelita Harapan Tangerang, Indonesia \\ sabrina.sihombing@uph.edu
}

\begin{abstract}
Corruption is one main national enemy in Indonesia. Three variables (i.e. personal values, religious values, and integrity) are as antecedent variables in explaining attitude toward corruption. This research aims to examine the relationship between personal values and religious values toward perception of integrity, and the relationship between integrity and attitude toward corruption. Data was collected through selfadministered questionnaire on Teacher College students in Banten, Indonesia. A non-probability sampling was applied in this study. The sample size of 250 respondents was set for this research. Structural equation modeling (SEM) was applied to analyze the data. This study applied structural equation modeling for analyzing data. The test results were mixed where two hypotheses were supported and one hypothesis was not substantiated. Specifically, this study found that perception toward integrity is not a significant predictor of attitude toward corruption. The paper provides an analysis of the data, a discussion of the findings and the directions for future research.
\end{abstract}

Keywords-personal values, attitude, intention, corruption, students

\section{INTRODUCTION}

Corruption is one main national enemy in Indonesia. News and report about corruption and people arrested because of corruption are exposed to Indonesian people almost every day. Corruption seems as part of Indonesian life. In relating with Indonesian current youth values, identified nine Indonesian youth values: mutual assistance, religion, democracy, kinship, hospitality, selfish, western culture, religious fanaticism, and corruption. [1]

Corruptions destroy nation and societies. Thus, many nations develop agencies to fight and minimize corruption such as Indonesia's Corruption Eradication Commission (Komisi Pemberantasan Korupsi, Indonesia), The Corrupt Practices Investigation Bureau (CPIB, Singapore), The Independent Commission against Corruption (ICAC, Australia), International Corruption Unit (ICU, United of Kingdom), and others.

Research in corruption shows that lack of integrity, positive personal values and religious values cause the domination of corruption in a society. [2] [3] [4] [5] [6] However, as far as researcher knowledge, there is no research has been conducted in Indonesia to predict the relationship between personal and religious values toward people perception toward integrity, and the influence of integrity perception to attitude toward corruption. These three variables (i.e. personal values, religious values, and integrity) are as antecedent variables in explaining attitude toward corruption. Thus, this research aims to examine the relationship between personal values and religious values toward perception of integrity, and the relationship between integrity and attitude toward corruption.

Attitude is defined as learned predisposition to behave consistently. [7] As a learned predisposition, attitude is an important variable in explaining people behavior. Specifically, attitude reflects what people think and feel. [8] It is a learned predisposition to act in a consistent way. [9] Many research shows that attitude is a significant predictor in predicting social phenomena such as voting behavior [10] [11] [12] buying behavior ${ }^{13,14,15,16}$ organizational behavior. [17] [18] [19] [20]

People attitude is formed through people perception. Specifically, perception is defined as the process by which people select, organize and interpret stimulus into a meaningful ${ }^{7}$. When people see things and then $s($ he) will through the process of learning about that things which then lead to people evaluation about that things (i.e. attitude). Research shows the relationship between people perception and attitude. [21] [22] [23] Thus, it is hypothesized that:

$H_{1}$ : The perception toward integrity will be positively related to attitude toward corruption.

Values influence all aspects of human life. [24] Homer and Kahle [25] proposed the hierarchy of value-attitude-behavior that describes the relationship of values to behavior is mediated by people attitude. Moreover, they further stated that values are abstract cognitions as a foundation for attitude. On the other hand, attitude is built based on perception. In particular, self-perception theory suggests that attitude is formed based on individuals' perception as the causes of their attitude. [26] Thus, it can be stated that personal values provide a foundation for people perception. In other words, it can be stated that personal values lead to people perception. Thus, it can be hypothesized that:

$\mathrm{H}_{2}$ : Personal values will be positively related to perception toward integrity.

$H_{3}$ : Religious values will be positively related to perception toward integrity. 


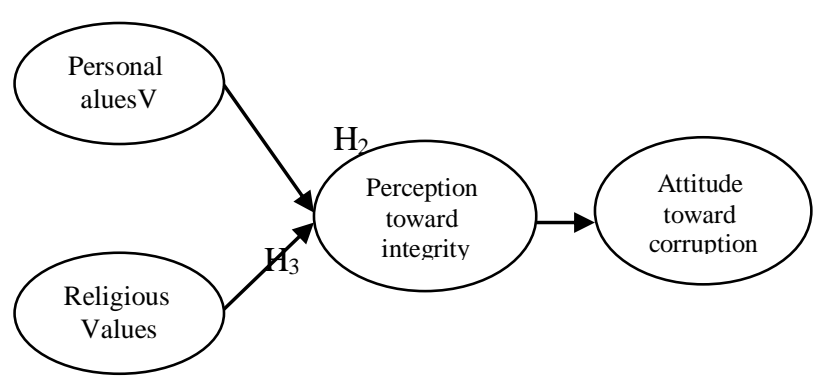

Figure 1. Proposed Research Model

Source: developed for this research (2016)

\section{RESEARCH METHOD}

\section{A. Data collection and sample size}

Data was collected through self-administered questionnaire on Teacher College students in Banten, Indonesia. A nonprobability sampling was applied in this study. This research applied structural equation modeling for analyzing data. The sample size was considered mainly in regard to the method used in analyzing data. Following [27] [28] the sample size more than 200 was set. In particular, any number above 200 provides sufficient statistical power in analyzing data. [29]

\section{B. Measures}

Items applied in this research were mainly adapted from previous studies. Specifically, personal values, religious values, and attitude toward corruption were measured by multi-item scales from prior research, that is Sihombing, Worthington et al. [30] Ajzen [31] respectively. Items for measuring perception toward integrity were scale development. In other words, item generation was based on a survey with open-ended questionnaires that were distributed to 500 respondents. [32] The main objective of the open-ended questionnaire is to identify respondent perception toward integrity. The results of that research identify six items for measuring perception toward integrity. The six items to measure perception toward integrity are (1) an honest person is a person who has integrity, (2) the responsible person is a person of integrity, (3) those who adhere to the principles reflect a man of integrity, (4) those who follow the rules are a person of integrity, (5) people who do not cheat reflect the integrity of the person, and (6) a disciplined person is a person of integrity.

Personal values. This research applied the short-form of the Indonesian Values Scale (INDVALS). The original scale consists of 13 values that include democracy (2 items), religion (5 items), and harmony (6 items) in representing Indonesian core values. However, this study applied only eight items (that is, democracy and harmony) in order to avoid overlapped with religious values. Specifically, those items are: (1) Democracy helps Indonesia become a better nation, (2) Election is a form of democracy in Indonesia, (3) Living in harmony, (4) Harmony prevents dispute, (5) Everyone should maintain harmony, (6) Harmony prevents separation, (7) Mutual assistance is a foundation in a social life, and (8) Helping each other is human social characteristic.
Religious values. Religious values were measured by using the Religious Commitment Inventory-10 (RCI-10) that was developed by Those ten items are: (1) I often read books and magazines about my faith, (2) I make financial contributions to my religious organization, (3) I spend time trying to grow in understanding of my faith, (4) Religion is especially important to me because it answers many questions about the meaning of life, (5) My religious beliefs lie behind my whole approach to life, (6) I enjoy spending time with others of my religious affiliation, (7) Religious beliefs influence all my dealings in life, (8) It is important to me to spend periods of time in private religious thought, (9) I enjoy working in the activities of my religious affiliation, and (10) I keep well informed about my local religious group.

Attitude toward corruption. This research used five items to measure attitude toward corruption. Specifically, a semantic differential scale was applied to measure the variable. A statement was given, that is, "In my opinion, corruption is activity that": (1) harmful-beneficial, (2) unpleasant-pleasant, (3) bad-good, (4) worthless-valuable, and (5) unenjoyableenjoyable.

\section{RESULST AND DISCUSSION}

A total of 233 questionnaires were returned out of 250 distributed. Thirty-three questionnaires were eliminated because of incomplete questionnaires. Therefore, 200 questionnaires that can be used in this research result a response rate of $80 \%$. The profile of the samples revealed that women constitute about 51.5 percent of the sample. Nearly two- thirds $(74.5 \%)$ of respondents ages ranged between 1820 years old.

Table 1 displays the correlations among the key constructs and reliability analysis (i.e. Cronbach alpha). All Cronbach alphas were greater than 0.7 for the four construct that exceeded threshold point of 0.70. [33] Table 1 also shows that all average variance extracted (AVE) estimate were greater than 0.5. [34]

\section{TABLE 1. SCALE PROPERTIES AND CORRELATION}

\begin{tabular}{|l|cccccc|}
\hline & \multicolumn{7}{|c|}{ Correlations } \\
\hline Variable & Reliability & AVE & 1 & 2 & 3 & 4 \\
\hline $\begin{array}{l}\text { 1. Integrity } \\
\text { 2. Personal } \\
\quad \text { Values }\end{array}$ & 0.879 & 0.78 & 1 & & & \\
$\begin{array}{l}\text { 3. Religious } \\
\quad\end{array}$ & 0.856 & 0.67 & $0.457^{* *}$ & 1 & & \\
$\begin{array}{l}\text { Values } \\
\text { 4. Attitude } \\
\text { toward } \\
\text { corruption }\end{array}$ & 0.985 & 0.98 & -0.007 & $0.190^{* *}-0.020$ & 1 \\
\hline
\end{tabular}

$* *$ Correlation is significant at 0.01 levels (2-tailed) Source: analysis of field data (2016)

Validity tests were performed after having done the reliability tests. Specifically, validity test was examined by an exploratory factor analysis (EFA) and confirmatory factor analysis (CFA). A valid EFA shows constructs in the same group and grouped into each respective component. Five items of religious values were deleted in the process of EFA in order 
to obtain convergent validity. Table 2 shows the EFA final validity result that demonstrates convergent validity.

TABLE 2. EXPLORATORY FACTOR ANALYSIS

\begin{tabular}{|l|cccc|}
\hline & 1 & 2 & 3 & 4 \\
\hline Integrity1 & & 0.784 & & \\
Integrity2 & & 0.732 & & \\
Integrity3 & & 0.649 & & \\
Integrity4 & & 0.731 & & \\
Integrity5 & & 0.824 & & \\
Integrity6 & & 0.807 & & \\
PersValue1 & & & 0.601 & \\
PersValue2 & & & 0.793 & \\
PersValue3 & & & 0.723 & \\
PersValue4 & & & 0.774 & \\
PersValue5 & & & 0.671 & \\
RelValue2 & & & & 0.616 \\
RelValue3 & & & & 0.577 \\
RelValue6 & & & & 0.592 \\
RelValue9 & & & & 0.735 \\
RelValue10 & & & & 0.795 \\
Attitude1 & 0.974 & & & \\
Attitude2 & 0.961 & & & \\
Attitude3 & 0.978 & & \\
Attitude4 & 0.977 & & \\
Attitude5 & 0.950 & &
\end{tabular}

This research also applied confirmatory factor analysis (CFA) to perform convergent validity. In particular, convergent validity was assessed by examining the parameter estimates and their associated t-values. [35] The result showed all parameter estimates ranging from 0.291 to 0.992 , with significant $t$-values. The CFA results show a chi-square value of 258.682 with 176 degrees of freedom (DF) at the $p=0.000$ level for a 1.470 chi-square/DF (the adjusted chi-square). Other fit indices show a good-fit model (GFI $=0.894, \mathrm{CFI}=$ $0.978, \mathrm{RMR}=0.040)$. The results show that the research measurement achieved convergent validity (Table 3 ).

\section{TABLE 3. CONFIRMATORY FACTOR ANALYSIS}

\begin{tabular}{|c|c|c|}
\hline Path & $\begin{array}{c}\text { Standardized } \\
\text { Regression } \\
\text { Coefficient }\end{array}$ & Critical Ratio \\
\hline Integrity $1 \leftarrow$ Integrity & 0.706 & \\
\hline Integrity $2 \leftarrow$ Integrity & 0.715 & 12.354 \\
\hline Integrity $3 \leftarrow$ Integrity & 0.698 & 8.877 \\
\hline Integrity $4 \leftarrow$ Integrity & 0.708 & 8.839 \\
\hline Integrity $5 \leftarrow$ Integrity & 0.739 & 9.252 \\
\hline Integrity $6 \leftarrow$ Integrity & 0.811 & 10.087 \\
\hline PersValue $1 \leftarrow$ PersValue & 0.591 & \\
\hline PersValue $2 \leftarrow$ Pers Value & 0.693 & 7.401 \\
\hline PersValue $3 \leftarrow$ Pers Value & 0.828 & 8.160 \\
\hline PersValue $4 \leftarrow$ PersValue & 0.713 & 7.527 \\
\hline PersValue $5 \leftarrow$ Pers Value & 0.557 & 6.275 \\
\hline RelValue $2 \leftarrow$ RelValue & 0.291 & \\
\hline RelValue $3 \leftarrow$ RelValue & 0.337 & 3.971 \\
\hline RelValue $6 \leftarrow$ RelValue & 0.509 & 3.527 \\
\hline RelValue $9 \leftarrow$ RelValue & 0.865 & 3.866 \\
\hline RelValue $10 \leftarrow$ RelValue & 0.839 & 3.865 \\
\hline Attitude $1 \leftarrow$ Attitude & 0.994 & \\
\hline Attitude $2 \leftarrow$ Attitude & 0.912 & 30.265 \\
\hline Attitude $3 \leftarrow$ Attitude & 0.992 & 84.955 \\
\hline Attitude $4 \leftarrow$ Attitude & 0.992 & 83.531 \\
\hline Attitude $5 \leftarrow$ Attitude & 0.897 & 27.768 \\
\hline
\end{tabular}

Table 1 (scale properties and correlation) before shows Pearson product-moment correlations among the study variables. The result provided support for discriminant validity. The highest correlation occurred between integrity and personal values (0.457) and reversely, the lowest correlation was found between attitude toward corruption and integrity (-0.007). Again, the results provide support for the discriminant validity of the scale. Based on the results in table 1,2 , and 3 , it can be concluded that construct validity was achieved.

After the goodness of measures process, the structural model was tested to test the hypotheses proposed. The results of the standardized estimate provided support for two hypotheses (Table 4) with a good fit values (i.e. Chi-square value of 271.048 with 178 degrees of freedom (DF) at the $p=$ 0.000 level for a 1.523 chi-square/DF; GFI $=0.889, \mathrm{CFI}=$ $0.975, \mathrm{RMR}=0.058$ )

\section{TABLE 4. PARAMETER ESTIMATES FOR} STRUCTURAL PATH

\begin{tabular}{|c|c|c|c|}
\hline $\begin{array}{l}\text { Hypothesized } \\
\text { relationship }\end{array}$ & Estimate & Critical Ratio & Conclusion \\
\hline $\begin{array}{l}\text { H1: Perception } \\
\text { toward integrity } \\
\rightarrow \quad \text { Attitude } \\
\text { toward } \\
\text { corruption }\end{array}$ & 0.019 & 0.252 & $\begin{array}{c}\text { Not } \\
\text { Supported }\end{array}$ \\
\hline $\begin{array}{l}\text { H2: } \quad \text { Personal } \\
\quad \text { values } \\
\text { Perception } \\
\text { toward integrity }\end{array}$ & 0.472 & 4.797 & Supported \\
\hline $\begin{array}{l}\text { H3: Religious } \\
\quad \text { values } \\
\text { Perception } \\
\text { toward integrity }\end{array}$ & 0.282 & 2.639 & Supported \\
\hline
\end{tabular}

This research attempted to examine the relationship between personal values and perception toward integrity, the relationship between religious values and perception toward integrity, and the relationship between perception toward integrity and attitude toward corruption. The test results were mixed where two hypotheses were supported and one hypothesis was not substantiated.

The rejection of the first hypothesis (that is, the perception toward integrity will be positively related to attitude toward corruption) may describe the phenomenon of corruption in Indonesia that have spread and depth in many areas. Corruption is a common word in everyday news or reports in Indonesian media. Many corruptors are arrested but corruptions still spread in many areas and many levels of Indonesian society. Indonesia can be stated as a country with the state of emergency in corruption. [36] [37]

A study conducted by Sihombing shows that Indonesian people are not exposed by the word of integrity as much as corruption. A research conducted by Transparency International Indonesia [38] also shows that many Indonesian youth cannot define the word of integrity, though they recognize behaviors that represent integrity. In summary, the relationship of perception of integrity and attitude toward 
corruption is not substantiated in this research. One main reason is that corruption phenomena are much exposed to Indonesian people but not with the word of integrity. Not only that, Indonesian leaders are seldom express their integrity in daily behavior as at least nine ministers, 19 governors, more than 300 regents/mayors, and two Indonesian central bank governors who have jailed because of corruption. [39]

Integrity is becoming a "product" that rare in which corruption is becoming increasingly common phenomenon. Not many leaders in Indonesia can provide examples of integrity. Moreover, media show Indonesian leaders that are corruptors and have been jailed but remain active in running the community organizations or are still in the government after they free from jail. Tragically, several ex corruptors have been promoted in government position. [40] [41] [42]

Social punishment for corruptors and their families continue to be debated in Indonesia in order to give deterrent effects. [43] [44] [45] However, Indonesian culture that tolerant and emphasize in harmony may inhibit the implementation of social punishment for corruptors and their families. Thus, corruption is still public enemy without strong cure that can reduce that problem.

\section{CONCLUSION}

This research contributes to the literature of corruption and integrity, especially in Indonesian context. However, this study has two main limitations that warrant in interpreting the research findings. First, the sample design of this research is applying nonprobability purposive sampling. Thus, the sampling design limits the ability to generalize the research findings. Therefore, further study may apply the probability sampling design. Second, this research applied cross-sectional design that only describes the respondents' perception and attitude at that time. Thus, further study may apply longitudinal study that can show the changes of perception and attitude, if any.

\section{REFERENCES}

[1] S.O. Sihombing. Identifying current values of Indonesian youth Proceeding of the $9^{\text {th }}$ International Conference on Business and Management Research, 24-25 October 2014, Kyoto University, Kyoto.

[2] J. Fedran, B. Dobovsek, B. Azman. Assessing the preventive anticorruption efforts in Slovenia. VARSTVOSLOVJE Journal of Criminal Justice and Security. 2015; 17(1): 82-99.

[3] Z.I. Wahyuni, Y. Adriani, Z. Nihayah. The relationship between religious orientation, moral integrity, personality, organizational climate and anti corruption intetions in Indonesia. International Journal of Social Science and Humanity. 2015; 5(10): 860-864.

[4] L.E. Sekerka. Preserving integrity in the face of corruption: exercising moral courage inh the path to right action. Journal of Organizational Moral Psychology. 2010; 1(3): 1-14

[5] G. Satiene, R. Toleikiene. A connection between corruption and unethical behavior of public officials. Social Research - Socialiniai tyrimai. 2007; 2(10): 155-160.

[6] W. Sandholtz, R. Taagepera. Corruption, culture, and communism. International Review of Sociology. 2005; 15(1): 109-131

[7] L.G. Schiffman, J.L. Wisenblit. Consumer behavior. $8^{\text {th }}$ ed. England: Pearson; 2015

[8] E.J. Arnould, L. Price, G.M. Zinkhan. Consumers. NY: McGraw-Hill Higher Education; 2004

[9] Wayne D. Hoyer, Deborah J. MacInnis. Consumer Behavior. Houghton Mifflin Company; 2007.
[10] E. Veer, I. Becirovic, B.A.S. Martin. If Kate voted conservative, would you? The role of celebrity endorsements in political party advertising. European Journal of Marketing. 2010; 44(3/4): 436-450.

[11] F. Kokkinaki. Attitudinal and normative influence on behavioral intentions: the moderating role of meta-attitudinal judgements within the Theor of Reasoned Action. Psychology, 2009;16(1): 28-43.

[12] T. Hansen. Understanding voters' decision: a theory of planned behavio approach. Innovative Marketing. 2007; 3(4): 87-94.

[13] H. Irianto. Consumers' attitude and intention towards organic food purchase: an extension of theory of planned behavior in gender perspective. International Journal of Management, Economics and Social Sciences. 2015; 4(1): 13-71

[14] S.P.S. Patiro, S.O. Sihombing. Predicting intention to purchase counterfeit products: extending the theory of planned behavior. International Research Journal of Business Studies. 2014; 7(2): 109-120.

[15] K.W. Tommy, M. Carissa, S.O. Sihombing. Predicting the influences of group conformity, utilitarian value, and product differentiation towards young adult's buying intention in smartphone. Jurnal Manajemen DEREMA. 2014; 9(1): 29-44

[16] C. Vinynda, S.O. Sihombing. Antecedents of Smart Phone Buying Behavior: an Empirical Study. Proceeding of UNISBANK International Conference, 29-30 August (2013), Semarang: Universitas Stikubank.

[17] H.A.H. Hettiararchchi, S.M.D.Y. Jayarathna. The effect of employee work related attitudes on employee job performace: a study of tertiary and vocational education sector in Sri Lanka. IOSR Journal of Business and Management. 2014: 16(4); 74-83.

[18] I. Khan, H. Dongping, T.A. Ghauri. Impact of attitude on employees performace: a study of textile industry in Punjab, Pakistan. World Applied Sciences Journal. 2014; 30: 191-197.

[19] A.K. Srivastav, P. Das. A study on employees attitude towards the organization and job satisfaction. International Journal of Science and Research. 2013; 4(7): 102-107.

[20] C. Mester, D. Visser, G. Roodt. Leadership style and its relation to employee attitudes and behavior. SA Journal of Industrial Psychology. 2013; 29(2): 72-82.

[21] A.Y. Yaakop, M.M. Anuar, K. Omar, A.L.K. Liung. Consumers perceptions and attitudes toward advertising on facebook in Malaysia World Business and Economics Research Conference, Auckland, NZ Retrieved from papers.ssrn.com/sol3/papers.cfm?abstract_id=2183787; 2012.

[22] X. Yang, L. Lu, G. Zhang, S. Lu, G. Xuan. Relationship between resort life cycle and residents' perception and attitude: a case study of Putuo Mountain. Chinese Geographical Science. 2004; 14(1): 90-96.

[23] N. Mvududu. A cross-cultural study of the connection between students attitudes toward statistic and the use of constructivist strategies in the course. Journal of Statistics Education, 11(3). Retrieved from www.amstat.org/publications/jse/vlln3/mvududu.html; 2003.

[24] M. Rokeach. The nature of human values. NY: Free Press; 1973

[25] P.M. Homer, L.R. Kahle. A structural equation test of the value-attitudebehavior hierarchy. Journal of Personality and Social Psychology. 1988; 54(4): 638-646

[26] L.G. Schiffman, L.L. Kanuk, J.L. Wisenblit. Consumer behavior $10^{\text {th }}$ ed. NJ: Pearson; 2010.

[27] M. S. Garver, J.T. Mentzer. Logistics research methods: Employing structural equation modeling to test for construct validity. Journal of Business Logistics. 1999; 20(1): 33-57.

[28] D. R. Hoelter. The analysis of covariance structures: Goodness-of-fit indices. Sociological Methods and Research. 1983; 11: 325-344.

[29] S.L. Hoe. Issue and procedures in adopting structural equation modeling technique. Journal of Applied Quantitative Methods. 2008; 3(1): 76-83.

[30] E.L. Worthington, N.G. Wade, H.L. Hight, J.S. Ripley, M.E. McCullough, J.W. Berry, M.M. Schmitt, J.T. Berry, K.H. Bursley, L. Conner. The religious commitment inventory-10 (RCI-10). Measurement Instrument Database for the Social Science. Retrieved from www.midss.ie 2012

[31] I. Ajzen. Constructing a TPB questionnaire: conceptual and methodological consideration. Retrieved from http://www.unibielefeld.de/ikg/zick/ajzen\%20construction\%20a\%20tpb $\% 20$ questionnaire.pdf

[32] S.O. Sihombing. Youth perception toward corruption and integrity: Indonesian context. Unpublished paper. Karawaci: Business School Universitas Pelita Harapan; 2015. 
[33] J. C. Nunnally. Psychometric theory $2^{\text {nd }}$ ed 1978. NY: McGraw-Hill.

[34] J. F. Hair, W. C. Black, B. j. Babin, R. E. Anderson. Multivariate data analysis 2010, NY: Maxwell Macmillan International Editions.

[35] R.P. Bagozzi, Y. Yi, and L.W. Philips. Asessing construct validity in organizational research. Administrative Science Quarterly. 1991; 36(3): 421-458.

[36] B. Duppa. KPK diobok-obok, MARS: Indonesia darurat korupsi. Retrieved from http://www.kabarmakassar.com/metro/kpk-diobok-obokmars-Indonesia-darurat-korupsi.html; 2012.

[37] M.H. Virdhani. BW bilang Indonesia darurat korupsi. Retrieved from http://national.sindonews.com/read/978500/13/bw-bilang Indonesiadarurat-korupsi-1426723803 2015.

[38] Transparency International Indonesia. Survey Integritas Anak Muda 2012. Retrieved

from http://www.ti.or.id/media/documents/2013/10/17/s/u/survei_integritas_a nak_muda_newsletter_1.pdf 2013.

[39] M.P. Ratya. Jokowi: 9 menteri, 19 gubernur, 300 bupati/walikota di penjara. Retrieved from news.detik.com/berita/3052911/Jokowi-9menteri-19-gubernur-300-bupatiwalikota-dipenjara; 2015.
[40] A.D. Muhanda. 9 terpidana korupsi masih menjabat di Pemda. Retrieved from http://www.solopos.com/2012/10/25/9-terpidana-korupsi-masihmenjabat-di-pemda-342208; 2012.

[41] I.D. Wedhaswary. Bekas koruptor jadi pejabat. Retrieved from lipsus.kompas.com/topikpilihanlist/2132/Bekas.Koruptor.Jadi.Pejabat; 2012.

[42] O. Yanto. Mafia hukum: membongkar konspirasi dan manipulasi hukum di Indonesia 2010. Jakarta: Penebar Swadaya Grup.

[43] K. Erdianto. Pemuda Muhhamdiyah dorong hukuman sosial bagi para koruptor. Retrieved http://nasional.kompas.com/read/2016/06/19/16021481; 2016.

[44] M. Sahana. Negara ini masih banyak memberi subsidi para koruptor. Retrieved from http://rri.co.id/yogyakarta/post/berita/230973/hukum__kriminal/negara_ini_masih_banyak_memberi_subsidi_para_koruptor.ht $\mathrm{ml} ; 2015$.

[45] A.Y. Prasetyo. Saatnya hukuman sosial bagi para koruptor. Retrieved from

http://nasional.kompas.com/read/2012/10/22/08253486/saatnya.hukuma n.sosial.bagi.para.koruptor; 2012. 